\title{
Orbitakompartment-szindróma
}

\author{
Arcot ért trauma következtében \\ leggyakrabban vakságot okozó állapot
}

\author{
Klenk Gusztáv dr. ${ }^{1}$ - Katona József $d r^{1}{ }^{1}$ - Kenderfi Gábor dr. ${ }^{1}$ \\ Lestyán János dr. ${ }^{1}$ - Gombos Katalin dr. ${ }^{2}$ - Hirschberg Andor dr. ${ }^{1}$
}

Szent János Kórház és Észak-budai Egyesített Kórházak, ${ }^{1}$ Fül-Orr-Gége és Szájsebészeti Osztály, ${ }^{2}$ Szemészeti Osztály, Budapest

Bevezetés: Az orbitakompartment-szindróma ritkán előforduló betegség, mégis az orbitát is érintő törések esetén ez okoz leggyakrabban vakságot. Az orbita nem táguló terében kis folyadéktöbblet, ödéma, vérzés jelentős nyomásfokozódást okoz, amely megszünteti a keringést az arteria centralis retinaeban és a szemideg ischaemiás nekrózisát, így vakságot okoz. A szem kidülled és a szemhéjak közé préselődik, a kötőhártya véresen, ödémásan megduzzad, a pupilla tágul, fénymerev lesz. Az eszméletén lévő beteg erős fájdalomról, feszülésről, hányingerről, kettős látásról, éleslátás-csökkenésről, majd megvakulásról panaszkodik. Csak az időben történő felismerés és haladéktalan sebészeti nyomáscsökkentés segíthet lateralis canthotomiával, cantholysissel. Ekkor a szem előrehelyeződésével az orbita térfogata megnő, nyomása csökken, a szemideg keringése helyreállhat, az ideg regenerálódhat és a látás visszatérhet. Célkitüzés és módszer: Kórházunkban 10 év alatt arccsonttörés mellett megvakult betegeink anyagának retrospektív feldolgozása a tanulságok levonásával.

Eredmények: 2007-2017 során 571 betegnél az arcközéptörés az orbitát is érintette. 23 beteg vakult meg. 17 betegnél a vakságot az orbitakompartment-szindróma okozta. Hat beteg esetében a retrobulbaris haematoma nem progrediált kompartmentszindrómába. Az orbitakompartment-szindróma létrejött kis és nagy törések, illetve kis és nagy haematomák mellett is. Hét betegnél a korai canthotomia és dekompresszió a látást megmentette.

Következtetés: Annak ellenére, hogy Magyarországon eddig (legjobb ismereteink szerint) csak egy cikk jelent meg e témában, feltételezhető, hogy az orbitakompartment-szindróma gyakrabban fordul elő. Ennek oka lehet, hogy a magyar egyetemi tankönyvekből kimaradt ez a fejezet, és a posztgraduális képzéseken sem esik róla szó. Traumás betegekkel kapcsolatba kerülő kollégák képzése szükséges, hogy ezt az egyszerüen kezelhető betegséget felismerjék és az orbitadekompresszió a korrekt sürgősségi betegellátás alapvető része lehessen.

Orv Hetil. 2017; 158(36): 1410-1420.

Kulcsszavak: orbitakompartment-szindróma, vakság, retrobulbaris haematoma, maxilla, zygoma, orbitatörés, arccsonttörés

\section{Orbital compartment syndrome}

\section{The most frequent cause of blindness following facial trauma}

Introduction: Although orbital compartment syndrome is a rare condition, it is still the most common cause of blindness following simple or complicated facial fractures. Its pathomechanism is similar to the compartment syndrome in the limb. Little extra fluid (blood, oedema, brain, foreign body) in a non-space yielding space results with increasingly higher pressures within a short period of time. Unless urgent surgical intervention is performed the blocked circulation of the central retinal artery will result irreversible ophthalmic nerve damage and blindness.

Aim, material and method: A retrospective analysis of ten years, 2007-2017, in our hospital among those patients referred to us with facial-head trauma combined with blindness.

Results: 571 patients had fractures involving the orbit. 23 patients become blind from different reasons. The most common cause was orbital compartment syndrome in 17 patients; all had retrobulbar haematomas as well. 6 patients with retrobulbar haematoma did not develop compartment syndrome. Compartment syndrome was found among patient with extensive and minimal fractures such as with large and minimal haematomas. Early lateral canthotomy and decompression saved 7 patients from blindness.

Conclusion: We can not predict and do not know why some patients develop orbital compartment syndrome. Compartment syndrome seems independent from fracture mechanism, comminution, dislocation, amount of orbital 
bleeding. All patients are in potential risk with midface fractures. We have a high suspicion that orbital compartment syndrome has been somehow missed out in the recommended textbooks of our medical universities and in the postgraduate trainings. Thus compartment syndrome is not recognized. Teaching, training and early surgical decompression is the only solution to save the blind eye.

Keywords: orbital comparment syndrome, retrobulbar heamorrhage, blindness, maxillofacial fractures, trauma

Klenk G, Katona J, Kenderfi G, Lestyán J, Gombos K, Hirschberg A. [Orbital compartment syndrome. The most frequent cause of blindness following facial trauma]. Orv Hetil. 2017; 158(36): 1410-1420.

(Beérkezett: 2017. július 10.; elfogadva: 2017. augusztus 3.)

\section{Rövidítések}

FESS = funkcionális endoszkópos sinussebészet; OKS = orbitakompartment-szindróma; $\mathrm{RBH}=$ retrobulbaris haematoma

A nyomásemelkedés zárt, azaz tágulni nem képes térben (fasciával, csonthártyával körbevett tér, azaz kompartment) hirtelen épül fel, ha a tér valamelyik összetevőjének tartalma megnövekszik, például vér: retrobulbaris haematoma $(\mathrm{RBH})$, ödéma, vagy idegen anyag kerül bele (agyi herniatio, idegen test), vagy a tér térfogata csökken (például blow-in törés az orbitában). A szövetnyomás emelkedése a vénás nyomás emelkedésével csökkenti az arteriovenosus gradienst $(\mathrm{Pa}-\mathrm{Pv})$, a keringést, a vér- és oxigénellátást.

$\mathrm{Az}$ emelkedett interstitialis ozmotikus nyomás és a hypoxia elsősorban az oxigéntartalmú szabad gyökök és egyéb mediátorok, a membrán- és kapillárispermeabili- tásra gyakorolt hatásának következtében tovább fokozzák az ödémaképződést, így tovább nő a kompartmentben a nyomás: „circulus vitiosus”. Az ischaemia akkor alakul ki, amikor a szövetek lokális autoregulációja kimerül, metabolikus és az oxigénigény nem biztosított. Ez a manifeszt kompartmentszindróma, amit már csak sürgős nyomáscsökkentő mútéttel, dekompresszióval lehet kezelni a végtagokon ugyanúgy, mint az orbita esetén. A végtagi és orbitakompartment-szindróma patomechanizmusa lényegét tekintve megegyezik.

Az orbita, a szemhéjaknál tömött rostos kötőszövettel, lateralis és medialis canthusok közti szemhéjakkal a csontos orbitához rögzített rugalmatlan, periosteumzsák (periorbita), amely tágulásra csak minimálisan képes.

A szemüregben felépülő nyomás a szemgolyót kifelé nyomja, ameddig a rugalmatlan canthusok engedik. A bulbust a fokozódó ödéma, vérzés a szemhéjak közé préseli. Amikor a bulbus tovább már nem tud előrehe-

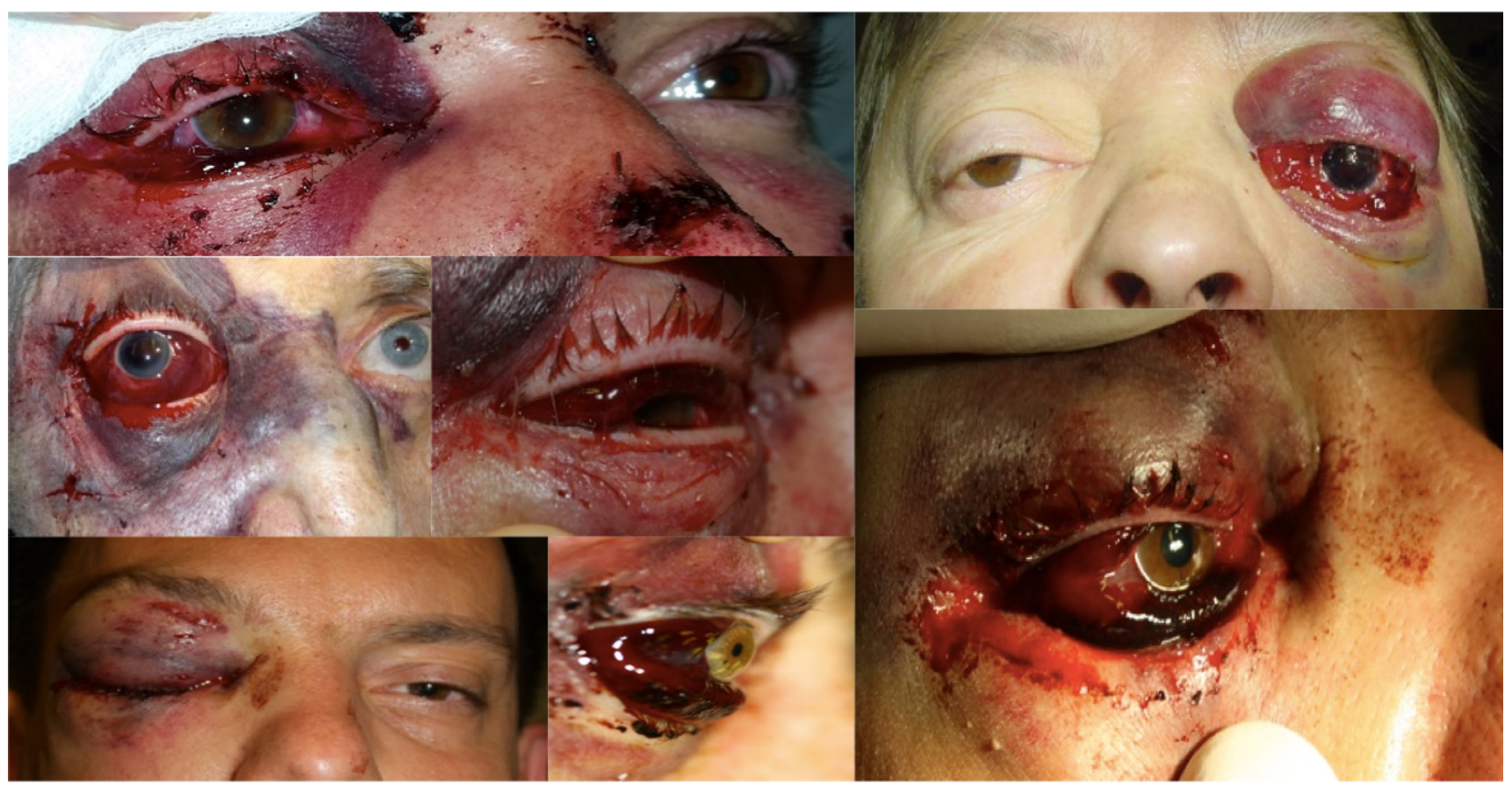

1. ábra Az orbitakompartment-szindróma jelei könnyen felismerhetőek 
lyeződni, azaz a térfogat nem tud tovább nőni, hirtelen megemelkedik a nyomás az orbitában (és a szemgolyóban is). A legérzékenyebbek a postciliaris, praelaminaris és choroidea kapillárisai, de a növekedő nyomás a centrális retinalis artériában is leállítja a vérkeringést, így a látóideg ischaemiás állapotba kerül, először átmeneti - reverzibilis, majd végleges - irreverzibilis károsodást szenved, azaz a szem kezdetben átmenetileg, majd véglegesen megvakul.

A patomechanizmus ismeretében az orbitakompartment-szindróma (OKS) tünetei, jelei könnyen felismerhetőek.

A szem kidülled, a szemmozgások csökkennek, a szemhéjak és conjunctivák sokszor ödémásak, suffundáltak, a szemfájdalom egyre erősödik, rosszulléttel, hányással kombinálódhat, kialakul a kettős látás, majd csökken a látásélesség, csökken az alak-, majd fényérzékelés, végül megszűnik a fénylátás, kialakul a vakság. Az afferens pupillareflexek múködése leáll. A pupilla kitágul és fénymerev lesz. A szemgolyó kemény (1.ábra).

Az OKS-kezelés sikeressége a hypoxia kialakulásától a beavatkozásig eltelt időtől függ. A korrekt diagnózis felállítása és azonnali kezelése a folyamatot visszafordíthatja, a szemideg múködése részben vagy egészben visszaállhat. A későn végzett dekompresszió esetén a nervus opticus irreverzibilis károsodása, nekrózisa, azaz végleges vakság következik be.

Mivel az elmúlt 10 évben kórházunkban sok, vaksággal kombinált arccsonttörött beteggel találkoztunk, ezért a tanulságok levonása céljából retrospektív analízist végeztünk.

1. táblázat | A 2007 és 2017 között osztályunkon kezelt betegek nemek és törés szerinti megoszlása

\begin{tabular}{|c|c|c|c|c|c|c|}
\hline Év & $\begin{array}{l}\text { Maxilla } \\
\text { Férfi/Nő }\end{array}$ & $\begin{array}{l}\text { Mandibula } \\
\text { Férfi/Nő }\end{array}$ & $\begin{array}{l}\text { Össz- } \\
\text { maxilla }\end{array}$ & $\begin{array}{l}\text { Össz- } \\
\text { man- } \\
\text { dibula }\end{array}$ & $\begin{array}{l}\text { Össz- } \\
\text { törés }\end{array}$ & Férfi/Nő \\
\hline 2007 & $55 / 17$ & $61 / 16$ & 72 & 77 & 149 & $116 / 33$ \\
\hline 2008 & $39 / 13$ & $54 / 13$ & 52 & 67 & 119 & $93 / 26$ \\
\hline 2009 & $28 / 2$ & $50 / 15$ & 30 & 65 & 95 & $78 / 17$ \\
\hline 2010 & $37 / 11$ & $47 / 12$ & 48 & 59 & 107 & $84 / 23$ \\
\hline 2011 & $39 / 9$ & $56 / 25$ & 48 & 81 & 129 & $95 / 34$ \\
\hline 2012 & $50 / 12$ & $85 / 20$ & 62 & 105 & 167 & $135 / 32$ \\
\hline 2013 & $65 / 16$ & $85 / 20$ & 81 & 105 & 186 & $150 / 36$ \\
\hline 2014 & $55 / 16$ & $64 / 14$ & 71 & 78 & 149 & $119 / 30$ \\
\hline 2015 & $45 / 14$ & $61 / 19$ & 59 & 80 & 139 & $106 / 33$ \\
\hline 2016 & $38 / 10$ & $76 / 16$ & 48 & 92 & 140 & $114 / 26$ \\
\hline $\begin{array}{l}2017 \\
\text { (április } \\
31 . \text { ) }\end{array}$ & $15 / 1$ & $18 / 6$ & 16 & 24 & 40 & $33 / 7$ \\
\hline Összesen & $466 / 121$ & $657 / 176$ & 587 & 833 & 1420 & $1123 / 297$ \\
\hline
\end{tabular}

\section{Betegek és módszer}

A 2007 és 2017 közti időszakban a vaksággal, RBH-val, OKS-sel hozzánk utalt betegek kórtörténetét dolgoztuk fel. A nemet, kort, kiváltó okot, a sérülés jellegét, a beutaló osztályokat és az általuk megállapított diagnózisokat, az elkészült képalkotó eljárásokat, a vakság kialakulásának feltételezhető okát, az OKS kezelésének eredményességét, illetve a beutaló diagnózisokban történt változásokat vizsgáltuk.

\section{Eredmények}

2007. január 1. és 2017. március 31. között intézetünkben arc-állcsont-koponya töréssel 1380 beteget kezeltünk, 574-et az orbitát is érintő arcközéptöréssel (1. táblázat).

Összesen 28 beteg került be a kritériumok alapján vizsgálatunkba különböző eredetû vaksággal, illetve RBH-val, OKS-sel (2. táblázat).

A 28 beteg közül 23-an az első vizsgálatkor már vakok voltak. A vakság oka 17 betegnél az OKS volt (3. táblázat).

Kormegoszlás: 21-82 évesek, átlag 53,1 év, 19 férfi, 9 nő. Az összes arc-állcsont törésre vonatkozóan a súlyos, szemet is érintő, illetve vaksággal járó kórképek előfordulása körülbelül 2\%, az orbitát is érintő arcközéptörésekre vonatkozóan mintegy $4 \%$ volt a gyakoriság.

Etiológia: ezek az orbitát (is) érintő törések leggyakrabban, kilenc betegnél esés következtében jöttek létre, közlekedési baleset következtében nyolc betegnél, testi sértés miatt öt betegnél, egyéb baleset miatt négy betegnél (szerelés közben rugó stb. csapódott a szemnek, ráeső tárgy által okozott orbitatörés).

A nőknél inkább az idősebb korosztály érintett. Etiológiában az elesés volt a leggyakoribb oka az arcközéptörésnek, míg a férfiak általában fiatalabbak, és inkább közlekedési baleset, testi sértés miatt alakult ki náluk törés.

OKS egyéb okokból is kialakulhatott: egy betegnél trauma következtében létrejött elülsőscala-törés az orbitatető diszlokációját okozta az orbitába (blow-in fractura), és a magas agynyomás (agyödéma) direkt orbitára gyakorolt hatását (agyi herniatio az orbitába) feltételeztük az OKS okaként.

Egy betegnél koponyaalapi törést követően pár nappal carotid cavernosus fistula alakult ki, pulzáló exophthalmussal, az egyik szem vakságával.

Egy esetben funkcionális endoszkópos sinussebészeti (FESS) mútét következtében, egy esetben pedig orbitomaxillaris törés során arcüreggyulladás az orbita szövetére terjedve okozott orbitaphlegmonét, abscessust következményes kompartmentszindrómával és vaksággal.

Négy esetben kizárható volt az OKS, így opticus laesiót feltételeztünk a vakság okaként, ekkor sem fizikális vizsgálattal, sem a sérülés után készült CT-felvételek alapján gyanú OKS-re nem merült fel: egy betegnél a canalis opticus törése és csontfragmentum által történő 
2. táblázat |A különböző eredetű vaksággal kezelt betegeink összefoglaló táblázata

\begin{tabular}{|c|c|c|c|c|c|c|c|c|c|c|c|}
\hline Név & Időpont & Nem & Kor & Etiológia & Beutaló & CT & $\begin{array}{l}\text { Beküldő } \\
\text { diagnózis }\end{array}$ & $\begin{array}{l}\text { Beavat- } \\
\text { kozásig } \\
\text { eltelt idő }\end{array}$ & Beavatkozás & Kimenetel & Kísérő \\
\hline P. E. & $\begin{array}{l}2007 . \\
\text { szeptember }\end{array}$ & Nő & 60 & Esés & Szemészet & Van & Blow-out & 2 nap & Canthotomia & Vak & Blow-out \\
\hline S. S. & $\begin{array}{l}2008 . \\
\text { augusztus }\end{array}$ & Férfi & 57 & Esés & Trauma & Kétszer & Laesio opticus & 3 nap & Gyógyszer & Vak & Zyg \\
\hline M. J. & 2009. április & Férfi & 36 & Testi erőszak & Trauma & Van & $\begin{array}{l}\text { Fáj, vak, } \\
\text { duzzadt }\end{array}$ & 9 óra & Canthotomia & Vak & Blow-out \\
\hline B. L. & 2009. június & Nő & 69 & Esés & Szemészet & Van & Maxillatörés & 1 óra & Canthotomia & LÁT!!! & Disp Zyg \\
\hline K. L. & $\begin{array}{l}2009 . \\
\text { szeptember }\end{array}$ & Férfi & 40 & $\begin{array}{l}\text { Közlekedési } \\
\text { baleset }\end{array}$ & Trauma & Van & Blow-out & 3 nap & Nem történt & Vak & Blow in is \\
\hline R. R. & $\begin{array}{l}2010 . \\
\text { szeptember }\end{array}$ & Férfi & 37 & Testi erőszak & Trauma & Van & $\begin{array}{l}\text { Koponyaalapi, } \\
\text { maxillatörés }\end{array}$ & 30 perc & Canthotomia & LÁT!!! & $\begin{array}{l}\text { Zyg+Orb tetô } \\
\text { blow out }\end{array}$ \\
\hline D. D. & $\begin{array}{l}2010 . \\
\text { november }\end{array}$ & Férfi & 21 & $\begin{array}{l}\text { Közlekedési } \\
\text { baleset }\end{array}$ & Trauma & Van & Zygomatörés & 7 nap & Canthotomia & Vak & $\begin{array}{l}\text { Blow in orb } \\
\text { tetőn is }\end{array}$ \\
\hline P. L. & 2012. október & Férfi & 33 & Esés & Idegsebészet & Kétszer & Fractura orbita & 3 nap & Nem történt & Lát-Vak & Zyg+ koponya \\
\hline V. R. & $\begin{array}{l}2012 . \\
\text { november }\end{array}$ & Férfi & 64 & Testi erőszak & Trauma & Van & Zygomatörés & 6-12 óra & Canthotomia & Vak & $\begin{array}{l}\text { Disloc nélküli } \\
\text { orb lat fala }\end{array}$ \\
\hline C. L. & $\begin{array}{l}2013 . \\
\text { november }\end{array}$ & Nő & 89 & $\begin{array}{l}\text { Közlekedési } \\
\text { baleset }\end{array}$ & Szemészet & Van & $\mathrm{RBH}$ & 1,5 óra & Canthotomia & LÁT!!! & Disloc zygoma \\
\hline R. A. & 2014. április & Nő & 83 & Esés & Szemészet & Van & $\mathrm{RBH}$ & 5 óra & Canthotomia & Vak & Blow-out \\
\hline R. A. & 2014. június & Férfi & 24 & $\begin{array}{l}\text { Közlekedési } \\
\text { baleset }\end{array}$ & Trauma & Van & $\mathrm{RBH}$ & & & $\begin{array}{l}\text { nem vak, } \\
\text { nincs } \\
\text { tünet }\end{array}$ & \\
\hline $\begin{array}{l}\text { S. L. } \\
\text { Gy. }\end{array}$ & $\begin{array}{l}2014 . \\
\text { augusztus }\end{array}$ & Férfi & 54 & Szerelés & Szemészet & Van & $\mathrm{RBH}$ & 2 óra & Canthotomia & $\begin{array}{l}\text { LÁT!!! } \\
\text { Szemész! }\end{array}$ & $\begin{array}{l}\text { Blow out, lat } \\
\text { orbit, orrcsont }\end{array}$ \\
\hline H. I. & 2015. február & Nő & 82 & Esés & Trauma & Van & $\mathrm{RBH}$ & 4 óra & Canthotomia & VAK! & $\begin{array}{l}\text { Medialis és } \\
\text { orbita alap }\end{array}$ \\
\hline T. L. & 2015. március & Férfi & 46 & Ruhafogas & Trauma & Van & $\mathrm{RBH}$ & 10 óra & Nem történt & VAK & $\begin{array}{l}\text { agyállományba } \\
\text { is hatolt }\end{array}$ \\
\hline P. L. & 2015. április & Férfi & 49 & Szerelés & Trauma & $\begin{array}{l}\text { Van, } \\
+ \text { MR }\end{array}$ & $\mathrm{RBH}$ & 2,5 óra & Canthotomia & $\begin{array}{l}\text { Vak- } \\
\text { LÁT!!! }\end{array}$ & $\begin{array}{l}\text { frontalis sinus, } \\
\text { orbitatető }\end{array}$ \\
\hline $\begin{array}{l}\text { J. M. } \\
\text { D. }\end{array}$ & 2015. április & Férfi & 29 & Testi erőszak & Trauma & Van & $\begin{array}{l}\text { RBH? Levegó, } \\
\text { blow-out }\end{array}$ & 2 óra? & Canthotomia & $\begin{array}{l}\text { Diplopia } \\
\text { csökken } \\
\text { LÁT }\end{array}$ & Blow out \\
\hline T. J. & 2015. április & Férfi & 46 & Testi erőszak & Trauma & Van & $\mathrm{RBH}$ & 5 & Canthotomia & $\begin{array}{l}\text { VAK- } \\
\text { LÁT!! }\end{array}$ & \\
\hline F. A. & 2015. március & Nő & 83 & Esés & Trauma & Van & $\mathrm{RBH}$ & & Nem történt & LÁT & Blow out \\
\hline J. Zs. & 2015. június & Nő & & ENT FESS & ENT & Van & $\mathrm{RBH}$ & Nem & Nem történt & $\begin{array}{l}\text { Csak } \\
\text { protrusio }\end{array}$ & \\
\hline M. J. & $\begin{array}{l}2015 . \\
\text { szeptember }\end{array}$ & Nő & 72 & Tárgy ráesett & Trauma & Van & $\mathrm{RBH}$ & & Nem történt & $\begin{array}{l}\text { Lát: } \\
\text { diplopia }\end{array}$ & $\begin{array}{l}\text { Blow out orb } \\
\text { explor recostr }\end{array}$ \\
\hline E. J. J. & $\begin{array}{l}2010 . \\
\text { augusztus }\end{array}$ & Férfi & 67 & $\begin{array}{l}\text { Közlekedési } \\
\text { baleset }\end{array}$ & Trauma & Van & Orbita-agyalap & - & Nem történt & $\begin{array}{l}\text { nem vak, } \\
\text { nincs } \\
\text { tünet }\end{array}$ & $\begin{array}{l}\text { Orbitattető, } \\
\text { RBH }\end{array}$ \\
\hline L. L. & $\begin{array}{l}2015 . \\
\text { december }\end{array}$ & Férfi & & $\begin{array}{l}\text { Orbita- } \\
\text { phlegmone }\end{array}$ & Trauma & Van & $\begin{array}{l}\text { Orbita- } \\
\text { phlegmone }\end{array}$ & & Drain, iv $\mathrm{AB}$ & Vak-Lát & \\
\hline $\begin{array}{l}\text { B. A. } \\
\text { R. }\end{array}$ & $\begin{array}{l}\text { 2015. április } \\
18 .\end{array}$ & Férfi & 37 & $\begin{array}{l}\text { Közlekedési } \\
\text { baleset }\end{array}$ & Szemészet & Van & $\begin{array}{l}\text { Orbita-apex } \\
\text { törés }\end{array}$ & 3 nap & Nem történt & VAK & $\begin{array}{l}\text { N. opt. } \\
\text { lesio-apexnél }\end{array}$ \\
\hline V. Á. & 2016. április & Férfi & 47 & $\begin{array}{l}\text { Közlekedési } \\
\text { baleset }\end{array}$ & Trauma & Van & $\begin{array}{l}\text { Agyalap } \\
\text { parietalis törése }\end{array}$ & - & Nem történt & VAK & N. opt. laesio? \\
\hline B. L. & 2017. február & Nő & 70 & Esés & Idegsebészet & Van & $\begin{array}{l}\text { Agyalap, } \\
\text { parietalis, } \\
\text { orbita } \\
\end{array}$ & Nem & Nem történt & VAK & N. opt. laesio \\
\hline K. L. & 2013. március & Férfi & 28 & $\begin{array}{l}\text { Közlekedési } \\
\text { baleset }\end{array}$ & Trauma & Van & $\begin{array}{l}\text { Carotid } \\
\text { cavernosus } \\
\text { fistula }\end{array}$ & $\begin{array}{l}\text { Intenzív } \\
\text { Osztály }\end{array}$ & Embolizáció & $\begin{array}{l}\text { VAK- } \\
\text { egyik } \\
\text { szem }\end{array}$ & $\begin{array}{l}\text { Agyalapi, } \\
\text { mandibulatörés }\end{array}$ \\
\hline C. S. F. & 2012 & Férfi & & Esés & Trauma & Van & $\begin{array}{l}\text { Nervus opticus } \\
\text { laesio! OKS: - / } \\
\text { RBH: - }\end{array}$ & - & Nem történt & VAK & $\begin{array}{l}\text { Orbito- } \\
\text { maxillaris fr. }\end{array}$ \\
\hline
\end{tabular}

disloc. $=$ diszlokált $; \mathrm{OKS}=$ orbitakompartment-szindróma; $\mathrm{RBH}=$ retrobulbaris haematoma 
3. táblázat |A betegeink vakságának hátterében feltételezhető okok

\begin{tabular}{lc}
\hline Vakság oka & Betegszám \\
\hline Orbitakompartment-szindróma & 17 \\
Nervus opticus laesio (1 apextörés) & 4 \\
Carotid cavernosus fistula & 1 \\
Orbitaphlegmone & 1 \\
\hline Összesen & 23 \\
\hline
\end{tabular}

4. táblázat $\mid \mathrm{Az} \mathrm{RBH} / \mathrm{OKS}$ gyakoriság arányát és a canthotomiák sikerességét összefoglaló táblázat

\begin{tabular}{|c|c|c|c|c|c|}
\hline Év & $\mathrm{RBH}$ & OKS & Canthotomia & $\begin{array}{l}\text { Első } \\
\text { találkozáskor }\end{array}$ & Kimenetel \\
\hline 2007 & 1 & 1 & Igen & 1 vak & 1 vak \\
\hline 2008 & 1 & 1 & $\begin{array}{l}\text { Nem } \\
\text { végeztünk }\end{array}$ & 1 vak & 1 vak \\
\hline 2009 & 3 & 3 & 2 esetben & 3 vak & $\begin{array}{l}2 \text { vak/ } \\
1 \text { lát }\end{array}$ \\
\hline 2010 & 3 & 2 & 2 esetben & 2 vak & $\begin{array}{l}1 \text { vak/ } \\
1 \text { lát }\end{array}$ \\
\hline 2011 & - & - & - & - & \\
\hline 2012 & 2 & 2 & 1 esetben & 2 vak & 2 vak \\
\hline 2013 & 1 & 1 & 1 esetben & 1 vak & 1 lát \\
\hline 2014 & 3 & 2 & 2 esetben & 2 vak & $\begin{array}{l}1 \text { vak/ } \\
1 \text { lát }\end{array}$ \\
\hline 2015 & 8 & 5 & 4 esetben & $\begin{array}{l}4 \text { vak, } 1 \\
\text { diplopia, } \\
\text { látásromlás }\end{array}$ & $\begin{array}{l}2 \text { vak/ } \\
3 \text { lát }\end{array}$ \\
\hline 2016 & - & - & - & - & - \\
\hline 2017 & 1 & - & $\begin{array}{l}\text { Nem } \\
\text { végeztünk }\end{array}$ & Vak & Vak \\
\hline 10 év & 23 & 17 & 14 & 16 & $\begin{array}{l}11 \text { vak/ } \\
7 \text { lát }\end{array}$ \\
\hline
\end{tabular}

$\mathrm{OKS}=$ orbitakompartment-szindróma; $\mathrm{RBH}=$ retrobulbaris haematoma

beszúkülése az orbita apexén okozott direkt idegsérülést. A másik három beteg esetén súlyos parietalis és koponyaalapi törés mellett nem sikerült egyértelmúen a kialakult vakság okát megállapítani. E betegek között két esetben a CT-felvételen minimális extraconalis vérzés azonban látható volt az orbitában $(\mathrm{RBH})$.

Koponya- és arcsérülések miatt mindegyik betegünknek volt az első ellátóhelyen készült CT-vizsgálata. Ennek alapján 23 betegnek volt RBH-ja, emellett 17 beteg esetében még OKS-t is diagnosztizálhattunk a CT-n az extrém bulbusprotrusio vagy a valós fizikális vizsgálat alapján. Az RBH tehát 74\%-ban szövődött OKS-sel (4. táblázat).

A 2. és 4. táblázatból látható, hogy csak azoknak a vak betegeknek a látását sikerült megmenteni, akiknél canthotomia történt. A dekompresszió eredményességét (látás!) azonban csak a sérüléstől, OKS létrejöttétől a beavatkozásig eltelt időintervallum határozta meg. A legfeljebb 2,5 órán belül elvégzett dekompresszió (hat beteg) esetén múlt el a vakság. Különleges szerencse, hogy egy betegnél a sérülés után körülbelül öt órával elvégzett dekompresszió is sikeres volt és a látás visszatért.

A késői dekompressziók hat beteg esetében jóval a tolerálható időn túl történtek meg, azoknál, akiknél az első találkozáskor még kifejezetten jelentős OKS-tüneteket láttunk. Bár ezen esetekben is csökkent az orbita feszülése, de a látóideg már irreverzibilisen károsodott, a vakság véglegesnek bizonyult.

Négy beteg esetén az első szakvizsgálat és a sérülés közt eltelt időszak a 10 órát meghaladta (egy beteg), illetve a 72 órát is (három beteg), ekkor - amikor már az orbita nyomása csökkent és a bulbusok helyzete is szinte normális - már nem láttuk reális értelmét az orbitadekompressziónak (5. táblázat).

Nem végeztünk dekompressziót a látásromlást nem mutató, csak részleges OKS-es (protrusio) esetekben sem. Ezeknél a betegeknél csak szoros obszervációt, gyógyszeres kezelést végeztünk.

Az OKS esetében inraocularisan vizsgálva ép bulbus mellett minimális eltérés látható a szemfenéken, ezért első betegeink nem kerültek sürgősségi szemészeti műtétre a szemészeti osztályon.

Kórházunkban OKS mindig $\mathrm{RBH}$ talaján alakult ki. $\mathrm{Az} \mathrm{RBH}$ mindig orbitát is érintő törés mellett jött létre. OKS kis, elmozdulás nélküli egyszerü és nagy diszlokációjú, súlyos, sok csontfragmentummal járó törések mellett is kialakulhatott, így létrejötte független volt az erőbehatás nagyságától és az elmozdulás mértékétől, illetve a CT-n látható vérzés mértékétől is.

A betegeket beutaló osztályok és a beutalókon szereplő diagnózisokat is áttekintettük. A beutaló diagnózisok között 2013-tól kezdve az RBH egyre gyakoribb lett.

5. táblázat |A sérülés-canthotomia között feltételezhető időintervallumsiker összefüggését bemutató táblázat

\begin{tabular}{lcl}
\hline $\begin{array}{l}\text { Sikeres } \\
\text { dekompresszió } \\
\text { idóintervalluma }\end{array}$ & $\begin{array}{l}\text { Sikertelen } \\
\text { dekompresszió: } \\
\text { a nervus opticus } \\
\text { végleges károsodása }\end{array}$ & $\begin{array}{l}\text { Akinél már nem } \\
\text { végeztünk } \\
\text { dekompressziót }\end{array}$ \\
\hline 1 óra & 4 óra & 10 óra \\
0,5 óra & 5 óra & 72 óra \\
1,5 óra & 6 óra & 72 óra \\
2 óra & 12 óra & 72 óra \\
2,5 óra & 48 óra & \\
2 óra & 168 óra & \\
5 & & Összesen: \\
\hline Összesen: 7 újra lát & $\begin{array}{l}\text { Összesen: } \\
6 \text { véglegesen vak }\end{array}$ & 4 véglegesen vak \\
\hline
\end{tabular}




\section{Megbeszélés}

Az OKS ritka betegség, de ha ismerjük, könnyü felismerni és diagnosztizálni. Még az eszméletlen, intubált beteg vizsgálatakor is egyértelmú a diagnózis: a szem kiemelkedik, kipréselődik a szemüregből (látható, elvileg mérhető [Hertell], bár a processus frontalis maxillae nehezen tapintható, ezért nem érdemes próbálkozni), a szemhéjak duzzadtak, véraláfutásosak (suffusio, haematoma), sokszor nem zárhatók, a kötőhártya erősen vizenyős, ödémásan elöreboltosul (chemosis) és a szaruhártya körül is bevérzik (ecchimosis), a pupilla kitágul, fénymerev lesz, tapintva a szem nyomása fokozódik, kőkemény. Tonometriát szükségtelen végezni, elég megtapintani. (Megjegyzendő, hogy a szemnyomás manuális vizsgálata nem feltétlenül javasolt, amíg az esetleges penetráló szemsérülést szemész szakorvos nem zárta ki.) A kialakult vakság és a hiányzó direkt pupillareflexek esetén azonban nem érdemes az időt ennél behatóbb szemészeti vizsgálatra vesztegetni.

Az eszméletén lévő beteg, hacsak a mentőben nem kapott erős fájdalomcsillapítót vagy szedálást, felhívja magára a figyelmet, nagyon fáj, feszül a szeme, a szem mozgatására ez még fokozódhat, rosszulléte, hányingere, hányása is lehet (paraszimpatikus tünet). A nyomás emelkedésével a szemgolyó kifelé mozdul el, a beteg arról számol be, hogy látása romlik, szemmozgása csökken (ophthalmoplegia), kettős látás, diplopia alakul ki, majd az érintett szem elveszti az alaklátását, fényérzékelését, megvakul. Ennek oka a hátsó rövid ciliaris artériák kompressziója, elzáródása és a látóideg elülső részének ischaemiás elzáródása. A szemfenék szemészeti vizsgálata során különösebb feltúnő elváltozás nem tapasztalható, esetleg enyhén sápadtabb az arteria centralis retinae belépési pontja, a látóideg pang, vérzések lehetnek a látóideg szélén, a retinaartériák constrictióban lehetnek [1-3] (6. táblázat).

A 2. táblázatból látható, hogy a 2007 szeptemberétől 2017 áprilisáig terjedő időszakban megvakult betegek száma 23. OKS miatt 17 beteg vakult meg, tehát a vakság leggyakoribb oka az OKS-volt.

\section{6. táblázat $\mid \mathrm{Az} \mathrm{RBH} / \mathrm{OKS}$ tünetei}

\begin{tabular}{l}
\hline A retrobulbaris haematoma tünetei Rowe szerint [3] \\
\hline 1. Szem fájdalma. \\
2. Csökkenő látásélesség, vakság (diplopia látás esetén). \\
3. Proptosis. \\
4. Szemnyomás növekedése (tapintás/tonometria). \\
5. Subconjunctivalis oedema (chemosis), haematoma (ecchimosis). \\
6. Opthalmoplegia. \\
7. Pupilla kitágul, direkt fényreflex elvesztése, konszenzuális \\
megtartottsága. \\
8. Retinaarteriolák constrictiója, discus opticus sápadtságával. \\
9. Ritkán cseresznyepiros maculafolt vénás obstrukció jeleivel. \\
\hline
\end{tabular}

OKS $=$ orbitakompartment-szindróma; $\mathrm{RBH}=$ retrobulbaris haematoma
7. táblázat Gyógyszeres kezelés OKS részleges tünetei esetén, ha vakság még nincs!

Javasolt gyógyszeres protokoll Kovács szerint [6]

1. Kortikoszteroid megadózisban! 3-4 mg/ttkg promt, majd 6 óránként $1-3 \mathrm{mg} / \mathrm{ttkg}$ iv

2. Mannitol $20 \% 200 \mathrm{ml}$ iv

3. Acetazolamid (Diamox) $500 \mathrm{mg}$ iv.

4. Papaverinum hydrochloricum $40 \mathrm{mg}$ iv.

OKS = orbitakompartment-szindróma

Volt év (2011, 2016), amikor nem találkoztunk OKSsel, de így is átlagosan évi körülbelül két esetben várható ilyen betegszámnál OKS. Ez az összes arccsonttörött beteg esetszámára lebontva mintegy $2 \%$. Ez megegyezik a szakirodalomban közöltekkel, azaz ritka, de valóságosan létező megbetegedés $[4,5]$.

Az összes betegünknél készült CT-felvétel a sérülést követően. RBH-t 23 esetben láttunk, de csak 17 esetben alakult ki OKS. Tehát minden OKS-ben találtunk RBH-t, de nem minden $\mathrm{RBH}$ progrediált OKS-sé. Az $\mathrm{RBH}$ szükséges, de nem elégséges feltételnek tûnik az $\mathrm{RBH}$ kialakulásában. Ezért, ha a CT-n RBH látható, de a szem jól látó (öt beteg esetén), szoros obszervációt és a konzervatív, gyógyszeres kezelés mérlegelését javasoljuk Kovács szerinti protokoll alapján: ahol a szteroid az orbita, a mannitol és acetalozamid a bulbus nyomását, a papaverin az érspasmust csökkenti [6,7] (7. táblázat). (Hypovolaemiás sokkban a vizhajtó, agysériulés esetén a szteroid kontraindikált lehet!) Ha ennek ellenére látásromlás észlelhető, akkor az azonnali sebészi dekompreszszió szükséges.

Az OKS-sel kezelt betegeink CT-vizsgálata alapján elmondható, hogy az OKS kialakulhat kis erőbehatás hatására létrejövő pici, szinte elmozdulás nélküli és nagy erőbehatás következtében létrejött, jelentős diszlokációval járó többszörös, darabos, romtörések esetén is. Kis és nagy vérzés mellett is előfordult OKS. A sérülés mértékéből tehát nem lehet előre megjósolni, ki vakulhat meg OKS miatt! Ezért minden sérült/operált potenciálisan veszélyben van! (Kis és nagy elmozdulások mellett létrejött RBH/OKS CT-képei: 2. ábra.) A CT-felvételeken az is megállapítható, hogy intraconalis (kis ciliaris artériák) és extraconalis (arteria infraorbitalis és perforáló ágai) vérzések mellett hasonló mértékben fordul elő OKS [3, 8-10].

A CT-vizsgálat a törések (és a vakság) korrekt diagnózisához, illetve a törések ellátásának műtéti tervezéséhez természetesen abszolút szükséges, de alapos indok nélkül nem előzheti meg a pár percet igénybe vevő dekompressziót [11-13].

Rowe [3] szerint a keringés megszünésétől 15-20 percen, Hueston és Heinze szerint $[8,9] 60$ percen túl irreverzibilis opticuselhalás, azaz végérvényes vakság következhet be. Bár a patomechanizmus szerint a nyomás egyre gyorsabban emelkedik, sokszor nehéz megtudni, mikor lépte át a kritikus szintet, mikor szűnt meg a látó- 


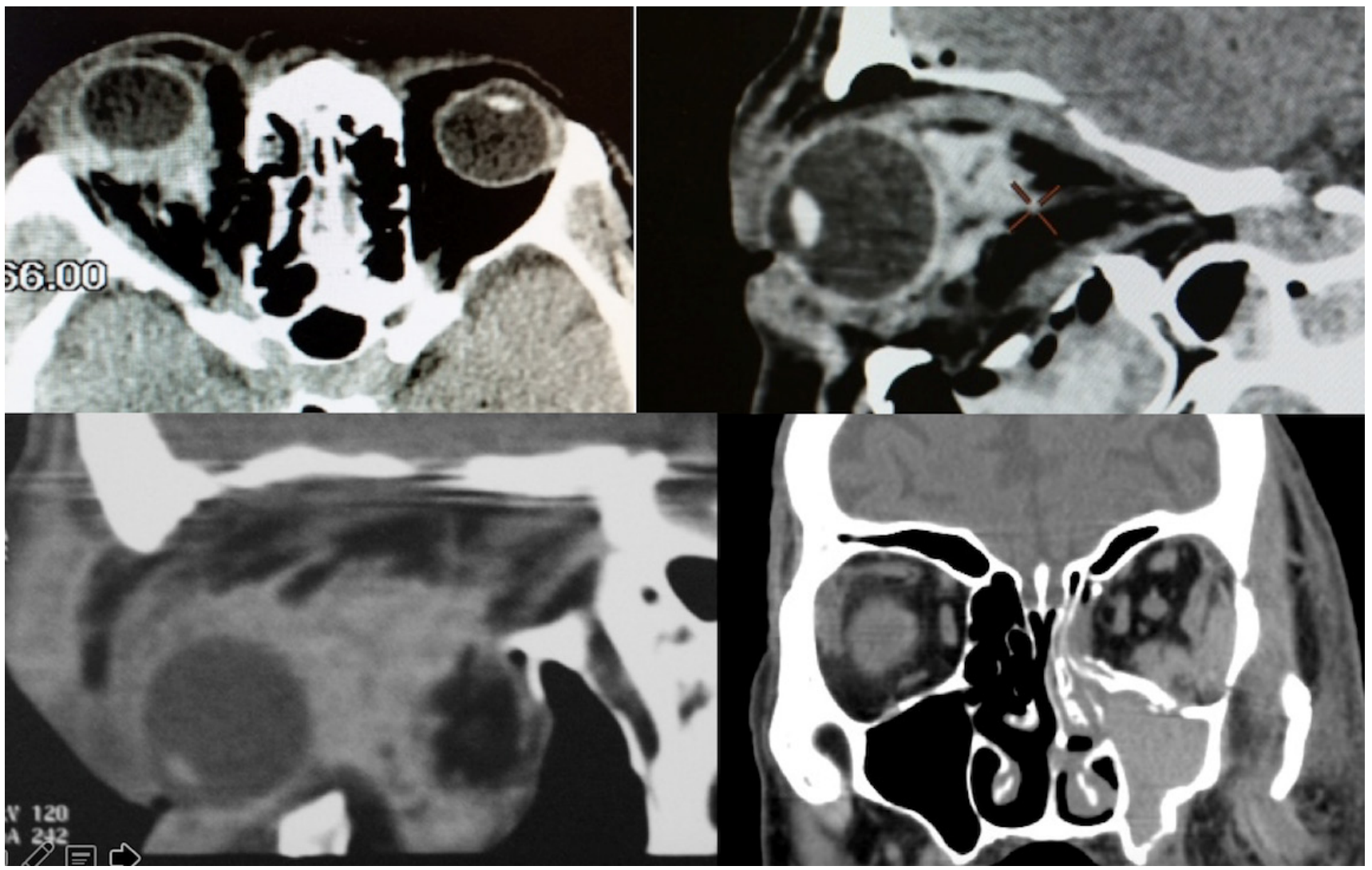

2. ábra $\mid$ Kiterjedt RBH/OKS képe axialis, sagittalis és coronalis CT-felvételeken

ideg vérkeringése és alakult ki a vakság. A kórházunkba érkezett OKS-es betegek többsége már vak volt, ezért azonnal el kellett volna végezni a nagynyomású orbita dekompresszióját („golden hour”), hogy a legjobb esélyt tudjuk biztosítani a látás visszatértére. Sajnos, a korai sebészeti dekompressziót, a siker egyetlen biztosítékát sokszor nem tudtuk időben elvégezni, mert a mindennapi gyakorlatban az arctörött eszméletvesztett vagy politraumatizált betegek többsége először az ügyeletes traumatológiára kerül, ahol túl sok idő megy el labor-, röntgen-, CT-vizsgálatokra, vizsgálati eredmények leírására és kiértékelésére, majd mentőszállításra, konzultációkra várakozva (5. táblázat) [14].

Az OKS következtében kialakult vakság diagnosztizálását követő első lépés, hogy akár helyi érzéstelenítésben a szem lateralis canthusát (ollóval-szikével) átvágjuk (canthotomia) és az alsó szemhéj canthusát a csontról leválasszuk (cantholysis), ezáltal az alsó szemhéjat ellazítjuk. Ennek hatására a szem kijjebb helyeződik a szemüregből (kifelé mozdul), az orbita térfogata megnő, a nyomás csökken (orbitadekompresszió), a látóideg keringése helyreáll. Ha nem tûnik kielégítőnek a dekompresszió, szükség lehet a felső szemhéj canthusának leválasztására is, illetve a periorbita bemetszésére is az alsó és lateralis egyenes szemizmok közt (interconalis RBH) [15]. Sikeres esetben az ideg múködése is lassan (napok, hetek) alatt rendeződik és a beteg újból látni kezd (3. ábra: a cantholysis, dekompresszió lépései). Egyes szerzők más utat is javasolnak, például a mútéti behatolási nyíláson át vagy infraorbitalis [3], vagy a szemöldökvonalban vezetett metszésből [16] és a lamina papyraceán keresztül FESS-mútéttel [17].

A cantholysis, az orbitotomia tehát nem elsősorban a vérömleny evakuálását (interstitialis?) és nem a vérzésforrás ellátását (postciliaris erek?) célozza meg (bár az extraconalis vérzés és haematoma elvileg könnyebben evakuálható, koagulálható) [2], hanem kizárólag az ödémából származó nyomás csökkentését hivatott biztosítani.

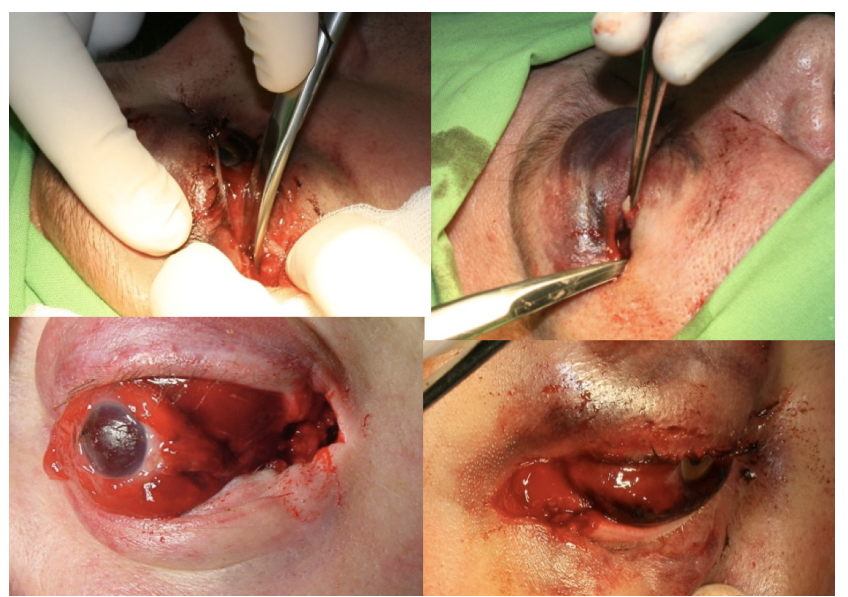

3. ábra A lateralis canthotomia-dekompresszió lépései 


\section{ORBITA-ELLENŐRZŐ LAP}

Páciens neve, TAJ, születés dátuma:

Osztály, Főorvos neve:

A retrobulbaris haematoma jelei és a vele kapcsolatos panaszok: egy vagy több a következök közül:

\section{FÁJDALOM \\ 2. CSÖKKENÖ LÁTÁSÉLESSÉG \\ 3. A SZEM FOKOZÓDÓ KIDÜLLEDÉSE \\ 4. PUPILLAREAKCIÓ CSÖKKEN \\ 5. PUPILLA KITÁGUL}

Ez az állapot irreverzíbilis vaksághoz vezethet. Ha gyanú van rá, az ügyeletes orvost azonnal értesíteni kell, mert azonnali beavatkozás szükséges!

Kérjük vizsgálja: 1 . Szemfájdalom: van $(\checkmark)$ nincs $(-)$

2. Látásélesség: normális $(\checkmark)$ csökkent (cs) vak (v)

3. Szemkidülledés: van $(\checkmark)$ nincs $(-)$

4. Pupilla-fényreakció: 1 = reagál, 2 = lassan reagál, 3 = nem reagál

5. Pupilla mérete: ( $1-7 \mathrm{~mm})$

\begin{tabular}{|c|c|c|c|c|c|c|c|c|c|c|c|}
\hline \multicolumn{2}{|c|}{$\begin{array}{l}15 \text { percenként } \\
\text { az első } 2 \text { brában }\end{array}$} & \multicolumn{2}{|c|}{$\begin{array}{c}\text { Orbitafijdalom } \\
(\checkmark /-)\end{array}$} & \multicolumn{2}{|c|}{$\begin{array}{l}\text { Látáśćlesség } \\
(\vee / \mathrm{cs} / \mathrm{v})\end{array}$} & \multicolumn{2}{|c|}{$\begin{array}{c}\text { Szem kidülledése } \\
(\checkmark /-)\end{array}$} & \multicolumn{2}{|c|}{$\begin{array}{l}\text { Pupillareakcí́ } \\
\text { (1-3) }\end{array}$} & \multicolumn{2}{|c|}{$\begin{array}{c}\text { Pupillaméret } \\
(1-7)\end{array}$} \\
\hline Dátum & Idổ & Jobb & Bal & Jobb & Bal & Jobb & Bal & Jobb & Bal & Jobb & Bal \\
\hline & & & & & & & & & & & \\
\hline & & & & & & & & & & & \\
\hline & & & & & & & & & & & \\
\hline & & & & & & & & & & & \\
\hline & & & & & & & & & & & \\
\hline & & & & & & & & & & & \\
\hline & & & & & & & & & & & \\
\hline & & & & & & & & & & & \\
\hline & & & & & & & & & & & \\
\hline \multicolumn{2}{|c|}{$\begin{array}{c}30 \text { percenként a } \\
\text { következó } 2 \text { orában }\end{array}$} & \multicolumn{2}{|c|}{$\begin{array}{c}\text { Orbitafájdalom } \\
(+/-)\end{array}$} & \multicolumn{2}{|c|}{$\begin{array}{l}\text { Látásélesség } \\
(\mathrm{n} / \mathrm{cs} / \mathrm{v})\end{array}$} & \multicolumn{2}{|c|}{$\begin{array}{c}\text { Szem kidülledése } \\
(+/-)\end{array}$} & \multicolumn{2}{|c|}{$\begin{array}{l}\text { Pupillareakcí́ } \\
\quad(1-3)\end{array}$} & \multicolumn{2}{|c|}{$\begin{array}{c}\text { Pupillaméret } \\
\text { (1-7) }\end{array}$} \\
\hline Dátum & Idó & Jobb & $\mathrm{Bal}$ & Jobb & Bal & Jobb & Bal & Jobb & $\mathrm{Bal}$ & Jobb & $\mathrm{Bal}$ \\
\hline & & & & & & & & & & & \\
\hline & & & & & & & & & & & \\
\hline & & & & & & & & & & & \\
\hline & & & & & & & & & & & \\
\hline
\end{tabular}

A nervus opticus jobban tolerálja a nyúlást, mint az oxigénhiányt, ezért az OKS vagy annak gyanúja esetén kijelenthető, hogy az orbitadekompressziós műtét rizikója elhanyagolható a beavatkozás hiányában létrejövő végleges vakságéhoz és annak a megszokott életmódra, munkavégzésre, hivatásra, életre gyakorolt hátrányos hatásához képest.

Bár a sérülés után pár órával (nappal) később végzett beavatkozásoknál már szinte semmi esély a sikerre, mert a beteg feltehetôen véglegesen megvakult, mi is végeztünk késői beavatkozásokat a még ekkor is erősen feszüló orbiták esetén (5. táblázat). Ilyenkor három dolgot mérlegelünk: 1. Nem tudni, milyen gyorsan épült fel a nyo- más, ezért adjunk egy esélyt! (Kis beavatkozással nagy eredmény!) 2. Ha mi már korrekt diagnózist írunk, ahhoz korrekt ellátást is illik társítani - orvosetikai szempont. 3. Mivel a betegség ritka, a beavatkozás elvégzése, kivitelezésének megismerése az ügyeletben dolgozó kollégáknak a szükséges gyakorlati tapasztalat megszerzésére adott esélyt.

Az egyik betegnél öt órával a sérülést követően elvégzett dekompresszió is sikerrel járt, ami igazolhatja kétségbeesett késői beavatkozásainkat.

A betegeink körében talált megvakult szemek mind trauma, az orbitát is érintő arc-, koponyaalapi, parietalis törések következtében jöttek létre. 
Mivel úgy tünik, az orbitát érintő törések [3-7, 10, $12,16,18-21]$ és mütéteik $[22,23]$ után fordulhat elő leggyakrabban $\mathrm{RBH} / \mathrm{OKS}$, ezért minden ilyen betegnél javasolható az angliai szájsebészeti osztályokon kötelező, korrekt monitorozást biztosító orbitaobszervációs táblázat kitöltése és aláírással történt hitelesítése. (Ennek magyar fordítása: 8. táblázat). Mivel az OKS a leggyakrabban az első négy posztoperatív vagy sérülés utáni órában alakulhat ki, ezért a monitorozást az első két órában 15 percenként, a következő két órában 30 percenként, majd óránként javasolják, amíg a kezelőorvos azt jónak látja, mivel statisztikailag akár az ötödik napig lehet még esély az OKS-re [24].

A monitorozás elmaradása miatt vakulhatott meg az a beteg, aki traumatológiai osztályra beérkezésekor még feltehetően látott (CT-n OKS tünetei), de négy nappal később, hozzánk utalva, már az OKS tüneteinek elmúlásával vak volt. A rendszeres monitorozás tehát szükséges minden olyan osztályon, ahol arccsontsérült beteget is kezelnek, megfigyelnek vagy orbitát is érintő mütéteket végeznek (osteotomia, tumor stb.).

Egy beteg esetében a vakság oka agyalapi törést követően pár nappal kialakuló carotid cavernosus fistula. A pulzáló exophthalmus és kialakuló vakság miatt sürgős idegsebészeti mútéttel sikerült a másik szem látását még megmenteni.

Egy beteg esetében az orbitatető blow-in törése (orbitatető orbita felé diszlokálódott lemeze), a fokozott intracranialis nyomás (agyödéma) szabadon tevődött át az orbitatartalomra és idézte elő az OKS-t. Időben történő idegsebészeti segítséggel történő orbitatető-rekonstrukcióval (agy-szemüreg elkülönítése), vagy canthotomiával elvileg a látást meg lehetett volna menteni, de az egyéb súlyos sérülések, életmentő beavatkozások, intenzív osztályos kezelés miatt a szájsebészeti szakvizsgálatra csak a sérülést követő hetedik napon került sor. Mivel a szem még így is exophthalmusban volt (blow-in és agyi herniatio) a canthotomiát elvégeztük, a visus szempontjából eredménytelenül. Ebben az esetben az agyi herniatio és agynyomás éppen úgy etiológiai faktornak tekinthető, mint az orbita térfogatát csökkentő, orbitába betörő felső fal (tető) blow-in fracturája (4. ábra).

Egy beteg öt nappal a sérülés után keresett fel minket vakságra panaszkodva. OKS-tünetek nem voltak, de a CT trauma következtében létrejött parietalis, agyalapi és az orbita-apexen létrejött törés miatt a canalis opticus beroppanását és az ideg diszlokált csontfragmentum miatti sérülését mutatta. Ilyen törés esetén a beavatkozás még intraoperatív navigáció segítségével is bizonytalan kimenetelú, különösen, ha a nervus opticus sérült, ezért nála kezelést nem tudtunk felajánlani [25].

Az orbitában megjelenő genny és ödéma, orbitaphlegmone szintén okozhat OKS-t. Egy betegünk esetében a szinte panaszmentes arcüreggyulladása terjedt kis elmozdulással járó maxillatörés mellett az orbita állományába. Az incisio, orbitotomia, genny drenálása, evakuálása és

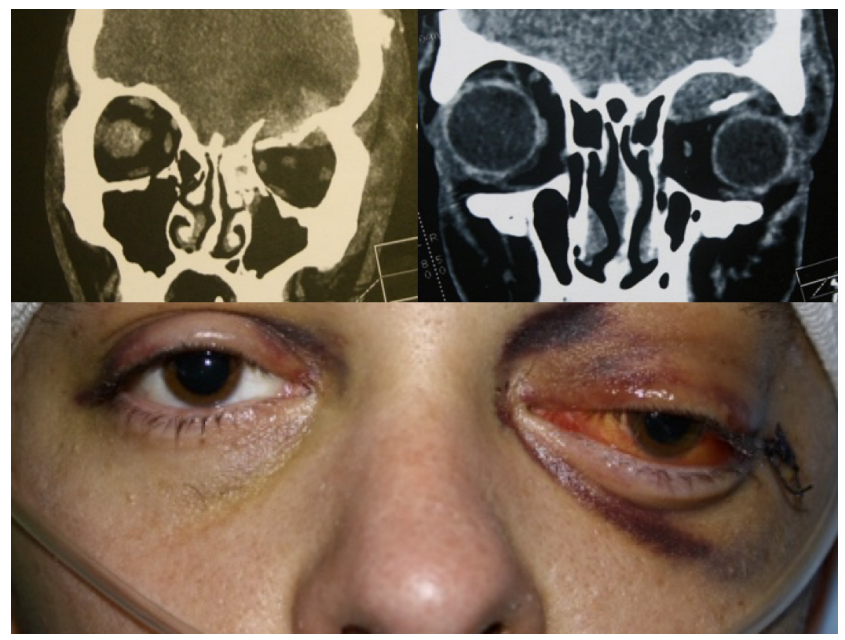

4. ábra

| Blow-in törés az orbitatetőn

az iv. antibiotikus kezelés hatására az intraorbitalis nyomás csökkent, a beteg látása részben visszatért.

Egy beteg esetében idegen test került az orbitába, következményes RBH-val, OKS-sel, vaksággal. Tíz órával a sérülés után került átmenetileg hozzánk, majd mivel az idegen test a scala mediába is behatolt, idegsebészeti osztályra küldtük tovább.

Egy beteg esetében funkcionális sinussebészet (FESS) következtében jött létre $\mathrm{RBH}$, ez azonban nem progrediált a látást befolyásoló OKS-be, így konzervatív kezeléssel rendeződött a protrusio és egyéb tünetek. A FESS következtében létrejövő OKS-t a leggyakoribb, orbitát érintő szövődménynek feltételezik [26-29]. (Általában a lamina papyracea sérülésének következménye.)

$\mathrm{Az}$ irodalomban ezenkívül leírnak az orbitát is érintő törések (maxilla-, zygoma-, homlokcsont-, izolált orbitatörések stb.) helyreállító mútéteinek (repozíciók, lemezes osteosynthesisek), maxilla-osteotomiák (Le Fort III-III) [30], felső impaktált bölcsességfog eltávolításának mútéti szövődményeként is OKS-t [31]. Szemészeti intraconalis injekciós érzéstelenítések és szemészeti mütétek kapcsán is létrejöhet OKS [32-41]. Ilyen esetekkel osztályunkon, kórházunkban nem találkoztunk.

A látást az időben végzett dekompresszióval 17 OKSbetegből hét esetében sikerült megmenteni, ez körülbelül 40\%-os siker.

A szakma szabályainak megfelelő ellátást az biztosíthatná, ha az első észlelő (mentőorvos, triage-kor a traumatológus) vagy elvégezné a dekompressziót, vagy már a mentő célba érkezése előtt megszerveznék a segíteni képes szakma képviselőjének is a megérkezését és a beavatkozás haladéktalan elvégzését a beteg kórházba érkezésekor [42-44].

Ha nincs életveszély, a labor-, EKG-, CT-, röntgenvizsgálatok nem előzhetik meg a dekompresszióhoz szükséges párperces beavatkozást! Hasonlóan a cardiopulmonalis resuscitatióhoz, a beteg stabilizálása is előnyt kell élvezzen az egyéb vizsgálatok előtt (illetve közben). Maxillofacialis szempontból a légutak biztosítása és a sú- 
lyos vérzés ellátása utáni harmadik legfontosabb sürgősségi teendó a proptotikus vak szem canthotomiája [25].

Súlyos sérült, eszméletlen beteg vizsgálatakor is mérlegelendő az elsőbbség, viszont, ha a CT-leletben már szerepel $\mathrm{RBH}$, mint ahogy mindegyik CT-leírásban szerepelt, ezen diagnózisnak fel kéne hívnia a betegért felelős orvos figyelmét a fenyegető vakság veszélyére, azonnali konzultációra, beavatkozásra.

\section{Következtetések}

Egy szem elvesztése a beteg egész életére, életmódjára, szakmájára, hivatására befolyással lehet, ezért a beteg szemének, látásának megmentése alapvető szakmai, erkölcsi, emberi, orvosi kötelesség. Javaslataink az elmúlt 10 év tapasztalatának fényében:

Mivel számos esetben leírtak az orbitát is érintő mütétek posztoperatív szövődményeként előforduló OKS-t, ezért ezt mint súlyos szövődményt a felvilágosító, betegbeleegyező nyilatkozatokba szükséges belefoglalni.

Javasoljuk az orbitát is érintő törések mútétei előtt a szemészeti státusz felvételét, hogy az esetleg posztoperatív időszakban bejelentett vakság esetén védhessük magunkat.

Amennyiben a sérült oldalon van a látó szem (például arccsonttörés), ennek helyreállítása az OKS ismeretében a teljes vakság elkerülése céljából mérlegelendő.

Mindegyik betegünk OKS-se orbitát (is) érintő törés és RBH mellett alakult ki. Az RBH tehát szükséges, de nem elégséges feltételnek látszik az OKS kialakulásában. Ezért, ha a CT-felvételen $\mathrm{RBH}$ látszódik vagy részleges OKS már kialakult, de a látás még megtartott, a beteg rendszeres ellenőrzése, illetve ennek alapján az orbitamegfigyelő lap kitöltése, gyógyszeres kezelés javasolt.

Az OKS klinikai diagnózis, ezért különösen eszméletén lévő, jó állapotú beteg esetén a CT felesleges időveszteség, csak a dekompresszió után javasolt a definitív diagnózis és törések ellátásának tervezéséhez.

Mivel a szakirodalomban gyakran írnak le OKS-t az orbitát is érintő mütétek, csontmútéteket követő első 24 órában, ezért ezen mütétek elvégzését az egynapos sebészeti beavatkozások keretein belül (day surgery) a szakmai kollégium álláspontjával szemben nem javasoljuk.

Az OKS-szindrómával foglalkozó cikkek gyakran $\mathrm{RBH}$ cím alatt jelennek meg. Úgy gondoljuk, hogy a haematoma az orvosok körében általában nem hordozza azt az azonnali beavatkozást sürgető és ijesztő diagnózist, amely mentálisan szükséges a sürgősségi beavatkozás azonnali lebonyolításához. Az RBH helyett ezért az OKS elnevezést javasoljuk.

Mivel saját korábbi cikkünkön kívül még nem találkoztunk hasonló témájú magyarországi közleménnyel [20], feltételezhetően az OKS-sel jelentkező betegek esetén sem korrekt diagnózis nem születik, sem korrekt kezelést nem végeznek, a betegek „ismeretlen eredetü okból” megvakulnak. 2,5-3 millió embert érintő ellátási körzetünk számadataiból kiindulva elképzelhető, hogy országosan évi mintegy hat-nyolc OKS és megelőzhető vakság is kialakulhat.

Eseteink történetei fel nem ismert betegségről tanúskodnak. Ennek oka lehet, hogy a jelenlegi magyar egyetemi oktatásban használt tankönyvekben ez a majd' 60 éve leírt betegség nem vagy nem kielégítően szerepel [45-51].

Összefoglalásként: Az OKS bár ritka, mégis létezik, könnyű felismerni és elvégezni a szükséges dekompreszsziót, de csak az időben végzett beavatkozás mentheti meg a látást! Nagyon kis beavatkozás nagyon komoly eredménnyel! De ismerni kéne az orvosi perek elkerülésére is. Ismert, de nem kezelt betegség következtében létrejött súlyos egészségkárosodás jogilag nehezen védhető a magyar ellátórendszer és kórházak számára. Ezért javasoljuk az OKS-t az egyetemi és posztgraduális képzés rendszeres részévé tenni, különösen a mentősök, traumatológusok, szemészek, fül-orr-gégészek, intenzív osztályokon dolgozók és (arc-állcsont) szájsebészek részére.

Anyagi támogatás: A közlemény megírása és a kutatómunka anyagi támogatásban nem részesült.

Szerzői munkamegosztás: A szerzők szakmai tudásukkal (H. A.), a betegek ellátásával (K. J., K. G.), a protokollok kialakításával (H. A.), az interdiszciplináris együttmúködés megvalósításában nyújtott segítséggel (G. K.), valamint az ellátott betegek adatainak gyújtésében és statisztikai feldolgozásában nyújtott segítséggel (L. J.) járultak hozzá a munkához. A levelező szerző (Klenk G.) a közlemény kitalálója, megírója, formára szabója, az irodalom feldolgozója, aki a betegek jó részét személyesen operálta, fényképezte, adataikat összesítette. A cikk végleges változatát valamennyi szerző elolvasta és jóváhagyta.

Anyagi érdekeltségek: A szerzőknek nincsenek érdekeltségeik.

\section{Köszönetnyilvánítás}

A levelező szerző külön köszönetét fejezi ki Dr. Kovács Ádám arc-, állcsont- és szájsebész professzor úrnak, tanítómesterének, aki a közlemény elkészülésében szakmai és emberi oldalról is támogatta.

\section{Irodalom}

[1] Hayreh SS. Anterior ischemic optic neuropathy. Springer Verlag, Berlin, Heidelburg, New York, 1975; pp. 21-23, 31-71, 123.

[2] Lima V, Burt B, Leibovitch I, et al. Orbital compartment syndrome: the ophthalmic surgical emergency. Surv Ophthalmol. 2009; 54: 441-449.

[3] Rowe NL. Fractures of the zygomatic complex and orbit. In: Rowe NL, Williams JL. (eds.) Maxillofacial injuries, Vol. 1. Churchill Livingstone, Edinburgh and London, 1985; pp. 435538 . 
[4] Ioannides C, Freihofer HP, Bruaset I. Trauma of the upper third of the face. J Maxillofac Surg. 1984: 12: 255-261.

[5] Magoon RC. Orbital fracture and retrobulbar haemorrhage. Am J Ophthalmol. 1963; 55: 370.

[6] Kovács Á. Maxillofacial traumatology. [Maxillofacialis traumatológia. Egyetemi tankönyv.] Semmelweis Kiadó, Budapest, 1999; pp. 145-146. [Hungarian]

[7] Ord RA, El Attar A. Acute retrobulbar haemorrhage complicating a malar fracture. J Oral Maxillofac Surg. 1982; 40: 234-236.

[8] Heinze JB, Hueston JT. Blindness after blepharoplasty; mechanism and early reversal. Plast Reconstr Surg. 1978; 61: 347-354.

[9] Hueston JT, Heinze JB. Second case of relief of blindness following blepharoplasty. Plast Reconstr. Surg. 1977; 59: 430-431

[10] Gillum WN, Anderson RL. Reversible visual loss in subperiosteal haematoma of the orbit. Ophthalmic Surg. 1981; 12: 203-209.

[11] Ord RA, Awty MD, Pour S. Bilateral retrobulbar haemorrhage: a short case report. Br J Oral Maxillofac Surg. 1986; 24: 1-6.

[12] Ashar A, Kovacs A, Khan S, et al. Blindness associated with midfacial fractures. J Oral Maxillofac Surg. 1998; 56: 1146-1150.

[13] Klenk G, Kovacs A. Do we need 3DCT in maxillo-facial surgery? J. Craniofac Surg. 2004; 15: 850.

[14] Perry M. Acute proptosis in trauma: retrobulbar hemorrhage or orbital compartment syndrome - does it really matter? J Oral Maxillofac Surg. 2008; 66: 1913-1920.

[15] McInnes G, Howes DW. Lateral canthotomy and cantholysis: a simple, vision-saving procedure. CJEM 2002; 4: 49-52.

[16] Fry HJ. Orbital decompression after facial fractures. Med J Aust. 1967; 1: 264-266.

[17] Kountakis SE, Maillard AA, Urso R, et al. Endoscopic approach to traumatic visual loss. Otolaryngol Head Neck Surg. 1997; 116(6 Pt 1): 652-655.

[18] Wood CM. The medical management of retrobulbar haemorrhage complicating facial fractures: a case report. Br J Oral Maxillofac Surg. 1989; 27: 291-295.

[19] Pigadas N, Lloyd RE. Haematoma of anterior ethmoidal artery after reduction of fracture of zygomatic complex. Br J Oral Maxillofac Surg. 2005; 43: 417-419.

[20] Klenk G. Blindness caused by retrobulbar hemorrhage (orbital compartment syndrome). [Retrobulbaris haematoma (orbitakompartment-szindróma) által okozott vakság.] Orv Hetil. 2010; 151: 1537-1544. [Hungarian]

[21] Klenk G, Katona J. Retrobulbar hemorrhage secondary to orbital blow out fracture. [Retrobulbaris haematoma Blow-out törés kapcsán.] Előadás a Magyar Arc-, Állcsont- és Szájsebészeti Társaság XI. Kongresszusán. Balatonalmádi, 2007. nov. 29. [Hungarian]

[22] Brauer T, Grossenbacher R. Blindness following reduction of a malar fracture. HNO 2007; 55: 211-216.

[23] Ord RA. Post-operative retrobulbar haemorrhage and blindness complicating trauma surgery. Br J Oral Surg. 1981; 19: 202207.

[24] Hayter JP, Sugar AW. An orbital observation chart. Br J Oral Maxillofac Surg. 1991; 29: 77-79.

[25] Perry M, Holms S. Atlas of operative maxillofacial trauma surgery. Springer Verlag, London, 2014

[26] Dunya IM, Salman SD, Shore JW. Ophthalmic complications of endoscopic ethmoid surgery and their management. Am J Otolaryngol. 1996; 17: 322-331

[27] May M, Levine HL, Mester SJ, et al. Complications of endoscopic sinus surgery: analysis of 2108 patients - incidence and prevention. Laryngoscope 1994; 104: 1080-1083.

[28] Neuhaus RW. Orbital complications secondary to endoscopic sinus surgery. Ophthalmology 1990; 97: 1512-1518.

[29] Saussez S, Choufani G, Brutus JP, et al. Lateral canthotomy: a simple and safe procedure for orbital haemorrhage secondary to endoscopic sinus surgery. Rhinology 1998; 36: 37-39.
[30] Li KK, Meara JG, Rubin P. Orbital compartment syndrome following orthognathic surgery. J Oral Maxillofac Surg. 1995; 53: 964-968.

[31] Goshtasby P, Miremadi R, Warwar R. Retrobulbar hematoma after third molar extraction: case report and review. J Oral Maxillofac Surg. 2010; 68: 461-464.

[32] Demere M, Wood T, Austin W. Eye complications with blepharoplasty or other eyelid surgery. A national survey. Plast Reconstr Surg. 1974; 53: 634-637.

[33] Hass AN, Penne RB, Stefanyszyn MA, et al. Incidence of postblepharoplasty orbital hemorrhage and associated visual loss. Ophthal Plast Reconstr Surg. 2004; 20: 426-432.

[34] Long JC, Ellis PP. Total unilateral visual loss following orbital surgery. Am J Ophthalmol. 1971; 71: 218-220.

[35] Carroll RP. Blindness following lacrimal nerve block. Ophthalmic Surg. 1982; 13: 812-814.

[36] Goldsmith MO. Occlusion of the central retinal artery following retrobulbar hemorrhage. Ophthalmologica 1967; 153: 191196.

[37] Mootha VV, Cowden TP, Sires BS, et al. Subperiosteal orbital hemorrhage from retrobulbar injection resulting in blindness. Arch Ophthalmol. 1997; 115: 123-124.

[38] Olitsky SE, Juneja RG. Orbital hemorrhage after the administration of sub-tenon's infusion anesthesia. Ophthalmic Surg Lasers 1997; 28: 145-146.

[39] Puustjarvi T, Purhonen S. Permanent blindness following retrobulbar hemorrhage after peribulbar anesthesia for cataract surgery. Ophthalmic Surg. 1992; 23: 450-452.

[40] DeMere M, Wood T, Austin W. Eye complications with blepharoplasty and other eyelid surgery. Plastic Reconstr Surg. 1974; 53: 634-637.

[41] Hueston JT, Heinze JB. Successful early relief of blindness occurring after blepharoplasty. Plast Reconstr Surg. 1974, 53: 588-592.

[42] Popat H, Doyle PT, Davies SJ. Blindness following retrobulbar haemorrhage - it can be prevented. Br J Oral Maxillofac Surg. 2007; 45: 163-164.

[43] Huang TT, Horowitz B, Lewis SR. Retrobulbar haemorrhage. Plast Reconstr Surg. 1977; 59: 39-44.

[44] Hislop WS, Dutton GN, Douglas PS. Treatment of retrobulbar haemorrhage in accident and emergency departments. Br J Oral Maxillofac Surg. 1996; 34: 289-292.

[45] Süveges I. (ed.) Ophthalmology. Textbook. [Szemészet. Egyetemi tankönyv.] Medicina Könyvkiadó, Budapest 2010. [Hungarian]

[46] Gőbl G. (ed.) Oxyology. [Oxiológia.] Medicina Könyvkiadó, Budapest, 2006. [Hungarian]

[47] Répássy G. (ed.): Ear-nose-throat-head and neck surgery. Text book. [Fül-orr-gégészet, Fej-nyak-sebészet. Egyetemi Tankönyv.] Medicina Könyvkiadó, Budapest, 2011. [Hungarian]

[48] Barabás J, Orosz M. (eds.) Oral surgery and dentistry. Textbook. [Szájsebészet és fogászat. Egyetemi Tankönyv.] Semmelweis Kiadó, Budapest, 2012. [Hungarian]

[49] Müller S. Treatment of medical urgencies. Memories, 7th revised edition. [Memorix - Sürgős esetek ellátása, 7. bővített kiadás.] Semmelweis Kiadó, Budapest, 2007. [Hungarian]

[50] Németh J, Farkas Á. Ophthalmology for dental students. Textbook. [Szemészet fogorvostan-hallgatóknak. Egyetemi Tankönyv]. Semmelweis Kiadó, Budapest, 2007. [Hungarian]

[51] Flautner L, Sárváry A. (eds.) Textbook of surgery and traumatology. [A sebészet és a traumatológia tankönyve.] Semmelweis Kiadó, Budapest, 2003. [Hungarian]

(Klenk Gusztáv dr.,

Budapest, Diós árok 1-3., 1125 e-mail: gusztavklenk@yahoo.co.uk) 